
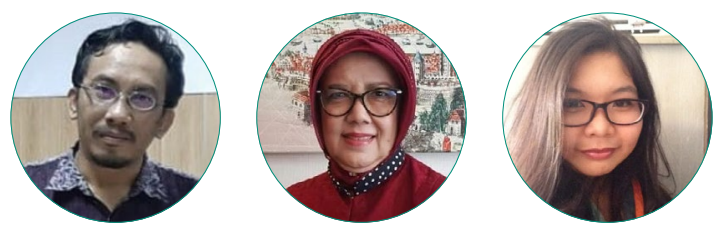

B. Kharisma, S.S. Remi, D. A. Maharani

\title{
THE IMPACT OF INDONESIA'S SCHOOL OPERATIONAL ASSISTANCE PROGRAM ON THE TRANSITION RATE FROM PRIMARY TO JUNIOR SECONDARY SCHOOL
}

\section{For citation:}

Kharisma B., Remi S. S., Maharani D. A. (2021) The Impact of Indonesia's School Operational Assistance Program on The Transition Rate from Primary to Junior Secondary School. Monitoring of Public Opinion: Economic and Social Changes. No. 5. P. 474-492. https:// doi.org/10.14515/monitoring.2021.5.1787.

\section{Правильная ссылка на статью:}

Харизма Б., Реми С. С., Махарани Д. А. Влияние Программы оперативной помощи школам на показатель перехода из начальной в младшую среднюю школу в Индонезии // Мониторинг общественного мнения: экономические и социальные перемены. 2021. № 5. С. 474-492. https://doi.org/10.14515/monitoring.2021.5.1787. (In Eng.) 
THE IMPACT OF INDONESIA'S SCHOOL OPERATIONAL ASSISTANCE PROGRAM ON THE TRANSITION RATE FROM PRIMARY TO JUNIOR SECONDARY SCHOOL

Bayu KHARISMA 1 -PhD., Department of Economics

E-MAIL: bayu.kharisma@unpad.ac.id https://orcid.org/0000-0002-2625-5250

Sutyastie Soemitro REMI ${ }^{1}$ - Professor, Department of Economics

E-MAIL: tatiremi@gmail.com https://orcid.org/0000-0001-7771-0367

Dinda Ayu MAHARANI ${ }^{2}$ - Research Assistant

E-MAIL: dindayumhrn@gmail.com https://orcid.org/0000-0001-5439-8497

\footnotetext{
${ }_{1}$ University of Padjadjaran, Bandung, Indonesia

2 Institute for Development of Economics and Finance (INDEF), Jakarta, Indonesia
}

Abstract. This study investigates the impact of Indonesia's School Operational Assistance Program (BOS) on the transition rate from primary to junior secondary school using data from the Indonesian Family Life Survey (IFLS) and the Difference-in-Differences method. The results showed that the School Operational Assistance Program (BOS) significantly increases the transition rate from Primary to Junior Secondary School. Meanwhile, the School Operational Assistance Program (BOS) is more effective in increasing the transition rate in girls compared to boys. When comparing rural and urban settings, the program is more effective in rural than urban areas. Despite results showing that the School Operational Assistance Program (BOS) has success-
ВЛИЯНИЕ ПРОГРАММЫ ОПЕРАТИВНОЙ ПОМОЩИ ШКОЛАМ НА ПОКАЗАТЕЛЬ ПЕРЕХОДА ИЗ НАЧАЛЬНОЙ В МЛАДШУЮ СРЕДНЮЮ ШКОЛУ В ИНДОНЕЗИИ

ХАРИЗМА Байю-кандидат экономических наук, департамент экономики, Паджаджаранский университет, Бандунг, Индонезия

E-MAIL: bayu.kharisma@unpad.ac.id https://orcid.org/0000-0002-2625-5250

РЕМИ Сутястие Соэмитро - профессор, департамент экономики, Паджаджаранский университет, Бандунг, Индонезия E-MAIL: tatiremi@gmail.com https://orcid.org/0000-0001-7771-0367

МАХАРАНИ Динда Аю - Стажер-исследователь, Институт развития экономики и финансов, Джакарта, Индонезия E-MAIL:dindayumhrn@gmail.com https://orcid.org/0000-0001-5439-8497

Аннотация. В статье исследуется влияние существующей в Индонезии Программы оперативной помощи школам (BOS) на показатель перехода детей из начальной в младшую среднюю школу с использованием данных Индонезийского национального обследования семей (IFLS) и метода сравнения разностей. Результаты показали, что Программа оперативной помощи школам значительно увеличивает этот показатель, однако она более эффективна в повышении коэффи циента перехода у девочек, нежели у мальчиков. При сравнении сельских и городских территорий оказалось, что Программа лучше работает в сельской местности, чем в городах. Несмотря на то, что полученные нами резуль- 
fully increased the transition rate from primary to junior secondary school, the program still has several problems, such as inadequate management of the funds and the lack of quality control related to its usage. The three models tested in the study conclude that the School Operational Assistance Program (BOS) significantly improved the overall transition rate from primary to junior secondary school in Indonesia, particularly for girls and rural areas.

Keywords: School Operational Assistance Program Program (BOS), transition rate from Primary to Junior Secondary School, difference-in-differences method, rural area, gender features of primary school education

Acknowledgments. This research is supported by DRPMI Universitas Padjadjaran (UNPAD) for Lecture Competency Research (RKDU) scheme. We thank our colleagues from the Department of Economics, who provided insight and expertise that greatly assisted the research and we thank "anonymous" reviewers for their so-called insights. таты свидетельствуют об успешности Программы в увеличении показателя перехода из начальной в младшую среднюю школу, в ее реализации, тем не менее, есть проблемы, например, неадекватное управление средствами и отсутствие контроля за их использованием. Три модели, протестированные в исследовании, показывают, что Программа оперативной помощи школам значительно улучшила общий показатель перехода из начальной в среднюю школу в Индонезии, особенно для девочек и сельских районов.

Ключевые слова: Программа оперативной помощи школам (BOS), показатель перехода из начальной в младшую среднюю школу, метод сравнения разностей, гендерные особенности образования младших школьников, сельские территории

Благодарность. Исследование поддержано программой DRPM Паджаджаранского университета (UNPAD). Мы благодарим наших коллег из департамента экономики, предоставивших важную для проведения исследования информацию, а также анонимных рецензентов за их вклад в улучшение статьи.

\section{Introduction}

Human capital is considered one of the most effective investments for countries that want to improve their long-term welfare. One aspect of focus for many nations is education, children's education in particular. Early evidence from Becker [1964] pointed out that education raises income later in life. According to the World Bank ${ }^{1}$, education is not only a human right but also "the strongest instrument for reducing poverty and improving health, gender equality, peace, and stability." Not only is education beneficial for the individuals receiving it, but education is also beneficial for society

\footnotetext{
1 The World Bank (2017, September 26) World Bank Warns of 'Learning Crisis' in Global Education. URL: https://www. worldbank.org/en/news/press-release/2017/09/26/world-bank-warns-of-learning-crisis-in-global-education (accessed: 10.10.2021).
} 
as it drives economic growth, triggers innovation, reinforces institutions, and nurtures social cohesion, as found by Barro [1991] and Mankiw, Romer, and Weil [1992].

Considering the importance of education to economic growth, it is no wonder that education has been a large part of global development strategies by the United Nations. Education is included in the Millennium Development Goals (MDGs) in the second goal, achieving universal primary education, and indicators for the third and sixth goals ${ }^{2}$. The Sustainable Development Goals also included education as the fourth goal, quality education. Thus, many developing countries have put education as their focus on fighting poverty and improving national welfare by increasing the national budget for education. These governments allocate their national budget on education through subsidy programs such as PROGRESA (Programa de Educación, Salud y Alimentación) in Mexico, PRAF (Programa de Asignación Familiar) in Honduras, PETI (Programa de Erradicaçao do Trabalho Infantil) in Brazil, and FA (Familias en Acción) in Colombia and BOS (School Operational Assistance) in Indonesia.

Indonesia's budget for education has increased significantly over the years. From 2001 to 2009 , the budget for education increased by over $120 \%$ in real terms. Most of the increase happened in 2009 when the budget increased by $20 \%$ over the previous year. The significant increase in the country's education budget is driven by the 2002 constitutional amendment that required the government to spend $20 \%$ of its total budget on education every year. Most of this budget is used for education reform in Indonesia, including teacher reform and school subsidies ${ }^{3}$.

A form of school subsidy the Indonesian government implemented is the School Operational Assistance Program (BOS). BOS in Indonesia initially started in 1998 as JPS (Social Safety Net Program). It was implemented as a response to the severe economic crisis happening in Indonesia at the time, intended to protect access to education for students from low-income households. The program was designed to be implemented from the $1998 / 1999$ to the $2002 / 2003$ academic year and consisted of two components: scholarship for students from low-income families and a block grant allocated to the schools [Kharisma, Satriawan, Arsyad, 2017].

After JPS, the government implemented BKM (Special Assistance for Students Program) for low-income students and BKS (Special Assistance for Schools Program) to help school operational costs. Later, the program was changed to BOS (School Operational Assistance Program) in 2005. One significant difference between BOS and the others is that the subsidy is given to the school instead of each student for operational expenses. The students receive a small amount of their BOS funds for a transportation allowance. When the program was first implemented in 2005, it was only allocated to low-income students who met specific criteria, giving those children free education. From 2009, each school is given a particular amount of funds according to the number of students, with each student in primary school level receiving IDR 235,000 every year, while students in junior secondary school receive IDR 324,500

\footnotetext{
2 The United Nations (2008) The Millennium Development Goals Report. URL: http://mdgs.un.org/unsd/mdg/Resources/ Static/Products/Progress2008/MDG_Report_2008_En.pdf (accessed: 10.10.2021).

3 World Bank. (2013) Indonesia - Spending More or Spending Better: Improving Education Financing in Indonesia. The World Bank Report. No. 73050. Jakarta (ID): World Bank. URL: https://openknowledge.worldbank.org/handle/10986/13210 (accessed: 09.10.2021).
} 
per year. Consequently, all students at primary and junior secondary schools have free education ${ }^{4}$. However, well-off students still pay some costs for extracurricular activities. At its inception, BOS was expected to improve the chances of a student completing nine (now twelve) years of basic education. By subsidizing basic education, the program aims to eliminate the cost of education and discourage students from dropping out of school. Previous evidence suggests that junior secondary schools' enrollment rates have been growing year to year, while primary school enrollment is constant at around $90 \%{ }^{5}$. The relatively lower enrollment rate in junior secondary school, according to Suryadarma, Suryahadi, and Sumarto [2006], is caused by the low transition rate from Primary to Junior secondary school.

Di Gropello [2003] defined transition rate as the number of students enrolled in the first grade of a higher level of education as a percentage of the number of students enrolled in the final grade of the lower level of education in the previous year. In other words, it's the percentage of the final grade students at a lower level of education who could continue to a higher level of education. It indicates the accessibility or transition from one level of education to another. It can be considered an indicator of output for the lower level of education and an indicator of accessibility for the higher level of education. The transition from one school level to another is critical to the school completion rate as most students drop out around this period.

The conditional cash transfer program in Mexico, PROGRESA, is found to increase the transition from $6^{\text {th }}$ grade to $7^{\text {th }}$ grade [Behrman, Sengupta, Todd, 2005; Schultz, 2004]. A similar cash transfer program in Cambodia for girls transitioning from elementary to secondary school also increased enrollment and 22 percentage points in any other school [Filmer, Schady, 2006]. Riccio et al. [2010] found similar results in a program called "Opportunity" implemented in New York City (US). The program increased school attendance and grade advancement for all the recipients. Furthermore, there has been a precedent of studies evaluating BOS and conditional cash transfer programs. In general, how BOS might affect transition rates from primary to junior secondary school has yet to be explored. This study aims to fill the gap in evaluating the BOS program. Evaluation is an integral part of evidence-based policymaking, and BOS is no exception. After fifteen years of implementation, it is essential to look at the policy's outcome and whether or not it has presented what it has promised. This is why the author has chosen to research the impact of the School Operational Assistance Program on school transition rates. Based on the description, this study aims to research and evaluate whether or not the School Operational Assistance Program (BOS) has succeeded in increasing the transition rates between primary and junior secondary schools and compare the results between genders and rural and urban areas.

This research makes a significant empirical contribution. There has not been any research on the impact of the School Operational Assistance Program (BOS) on school

\footnotetext{
${ }^{4}$ Srihadi E. (2005) Evaluasi Rencana Kebijakan Program Kompensasi Pengurangan Subsidi Bahan Bakar Minyak. Jakarta (ID): The Indonesian Institute. URL: https://www.neliti.com/publications/45113/evaluasi-rencana-kebijakan-programkompensasi-pengurangan-subsidi-bahan-bakar-mi\#cite (accessed: 09.10.2021).

5 Al-Samarrai S. (2015) Improving Education through the Indonesian School Operational Assistance Program (BOS). Policy Brief. No. 96507. Jakarta (ID): Education Global Practice World Bank. URL: https://documents1.worldbank.org/ curated/en/525301468183561575/pdf/96507-REVISED-BRI-ENGLISH-PUBLIC-Box391467B-BOS-Review-PolicyBrief-28May2015.pdf (accessed: 09.10.2021).
} 
transition between primary and junior secondary schools and comparing outcomes between genders and rural and urban areas using panel data in Indonesia.

\section{Theoretical background}

To construct a model of optimal cash transfer, we will adopt the model from de Janvry and Sadoulet [2006]. In the model, $P(X, T)$ denotes the probability that a child with characteristics $X$ and eligible for a transfer $T$ will enroll in school. Meanwhile, eligibility is denoted by the function $I \in[0,1]$. The children's characteristics are distributed according to the density function $f(X)$. The main problem of allocation is choosing the eligibility status $I(X)$ and, if eligible, the amount of conditional transfer $T(X)$ offered to a child with characteristics $X$, to maximize the gain in enrollment over the population:

$$
\max _{I(X), T(X)} \int[P(X, T)-P(X, 0)] I f(X) d X
$$

Subject to a budget constraint:

$$
\int P(X, T) T I f(X) d X \leqslant B \text {. }
$$

Where $B$ is the available budget for the program. For any eligible child $(I=1)$, the first-order condition for the optimal conditional transfer is:

$$
P_{T}-\lambda\left(P_{T} T+P\right)=0
$$

Where $P_{T}=\frac{\partial P}{\partial T}$ and $\lambda$ is the Lagrange multiplier associated with the budget constraint. The relationship states that the ratio of $\operatorname{cost}\left(P_{T} T+P\right) d T$ to enrollment benefit $\left(P_{T} d T\right)$ of a marginal increase in the conditional transfer $(d T)$ is equal for all children. Therefore, the cost of the marginal child brought to school is equal for all children types $X$. The cost of enrollment has two terms. The first term, $\left(P_{T} T d T\right)$, is the transfer cost to the $P_{T} d T$ marginal children brought to school by the increase in conditional transfer. The second term, $P d T$, is the cost of the increasing transfer, $d T$, to all $P$ children of the same type $X$, even though they enrolled in school with the initial transfer $T$. The marginal equivalent of the decomposition of the cost of the transfer is:

$$
P(X, T) T=[P(X, T)-P(X, 0)] T+P(X, 0) T .
$$

Where the first term represents the cost of the transfers to the children attending

school due to the conditional transfer, and the second term is the cost of the transfers to the children who would have gone to school either way. Given the optimal transfer conditional on eligibility, the optimal eligibility rule is defined by:

$$
I=1 \text { if }(P(X, T)-p(X, 0))-\lambda P(X, T) \geqslant 0, I=0 \text { otherwise. }
$$

The optimal allocation of budget $B$ is thus the solution to the system (2), (3), and (4). In the case of a linear probability model as used in the empirical work here, the conditional expectation of the enrollment probability is:

$$
E P(X, T)=X \beta+\delta_{0} l+X \delta T
$$


Where $\delta_{0} l+X \beta T$ is the total impact $T$ and $X_{\delta}$, which includes a constant term, is the marginal impact of $T$. The optimal transfer and eligibility criteria defined in equations (3) and (5) are written:

$$
T=\max \left(\frac{1}{2 \lambda}-\frac{1}{2} \frac{X \beta+\delta_{0}}{x \delta}, 0\right)
$$

Where $\lambda$ is a solution to the budget constraint (2). The expression shows that both eligibility and optimal transfer for any child are a function of the ratio

$$
X \beta+\delta_{0} / X_{\delta}=E P(X, 0)+\delta_{0} / E P_{T} .
$$

The first term is the expected probability that children with characteristics $X$ would go to school without a transfer, and the denominator is the marginal effect of the transfer on the expected enrollment probability. From this, we find that children will be eligible and receive high transfers if they have a low initial probability of enrollment and/or a high enrollment response to a transfer.

\section{Overview of the School Operational Assistance (BOS) in Indonesia}

The School Operational Assistance Program (BOS) is not the first school subsidy program in Indonesia. In the President Soeharto era in 1973-1974, a sizeable amount of money was allocated to the Primary school construction project called SD Inpres Project. Between the 1973/1974 and 1978/1979 academic year, 61,807 new schools were constructed in Indonesia, costing over USD 500 million by the 1990 exchange rate [Duflo, 2001]. The budget came from the oil boom revenue from 1973 to 1980 . Each new school was required to enroll 120 students with three teachers, with local governments obligated to provide additional subsidies if the funding was insufficient. The results suggested that an investment in infrastructure increases school enrolment and educational attainment, which in turn increases earnings.

After the Asian economic crisis hit Indonesia in 1998, the government launched the Social Safety Net Program (JPS). JPS was intended to assist low-income families affected by the crisis, particularly in education expenditure. JPS consisted of a scholarship for students and a block grant for schools. The scholarship was given directly to the students to support household expenditures during the crisis, while the block grant was given to schools so they would be able to keep operating. The subsidy was given to $6 \%$ of primary school students, $17 \%$ of junior secondary school students, and $10 \%$ of high school students. Elementary, junior secondary school, and high school students get IDR 120,000, IDR 240,000, and IDR 300,000 each year, respectively. Eligible students are from low-income families, attending grades four, five, and six for primary school or attending any grade in junior secondary school and high school, and students who dropped out or are vulnerable to dropping out for economic reasons.

The Indonesian government reduced the fuel subsidy in 2001 and allocated the funds to education, health, and infrastructure. The government introduced other assistance programs, Special Assistance for Students (BKM) and Special Assistance for Schools (BKS). It was motivated by the reduction in fuel subsidies and is intended to fully replace JPS by August 2003. The program lasted from 2001 to 2004 [Sulistyaningrum, 2016]. BKM and BKS were replaced with the School Operational 
Assistance program in 2005. The assistance is given to reduce the burden of financing education for low-income households, especially with the rise in fuel prices. However, BOS funds were distributed through the schools instead. At its inception, low-income students were prioritized for BOS, while higher-income students still had to pay some fees, albeit at a reduced amount. Each school is given a specific amount of funds according to the number of students. Each student in the primary school level receives Rp IDR 235,000 per year, while students in junior secondary school receive IDR 324,500 per year ${ }^{6}$. The idea was that the BOS program could support each school in financing their operational costs, such as textbook procurement, school exams, general and daily tests, consumables procurement, stationery, maintenance costs, electricity and telephone costs, student activities costs (remedial, extracurricular).

The BOS policy was changed in 2009 to include all students registered at elementary and Junior secondary schools regardless of economic background. Its main purpose is to ensure that all school-age children can go to school without paying any school operational costs. Besides, low-income students get additional assistance for transportation and a uniform allowance. Moreover, in 2009, the government changed the objective of BOS from only accelerating the 9-year basic education program to adding another goal - increase the quality of basic education. The amount of money was also increased to IDR 400,000 per student per annum for primary schools and IDR 575,000 for junior secondary.

\section{Method}

This research will use data derived from the Indonesian Family Life Survey (IFLS), as collected by RAND Corporation, in the form of panel data from IFLS-3 and IFLS-4 from 2000 and 2007 to estimate the period before BOS was implemented and the period after BOS was implemented in 2005. IFLS is a longitudinal survey in social economy and health that has been done since 1993, with the latest in 2014 to early 2015. The method used in this research is impact evaluation using the panel fixed effects model. As the program has been implemented, the evaluation is ex-post. The doubledifference method (DD) compares the treatment and comparison groups in outcome changes relative to the outcome observed before the treatment. This method is used considering that BOS was not distributed randomly, and the available data makes it possible to use this method. This research will mostly take JPS (a pre-cursor to BOS) analysis on drop-out rates [Giles, Satriawan, 2015]. However, the transition rate will be used instead of the drop-out rate. According to the Handbook on Impact Evaluation [Khandker, Koolwal, Samad, 2009], the basic model of a double-difference method in estimating average program impacts is as follows:

$$
D D=E\left(Y_{1}^{T}-Y_{0}^{T} \mid T_{1}=1\right)-E\left(Y_{1}^{c}-Y_{0}^{c} \mid T_{1} 0=0\right)
$$

The double-difference method uses a two-period setting where $t=0$ is a period of time before the program is implemented and $t=1$ is a period of time after the program is implemented. $Y_{1}^{T}$ and $Y_{0}^{T}$ denotes the outcome for a treated individual after

\footnotetext{
${ }^{6}$ Srihadi E. (2005) Evaluasi Rencana Kebijakan Program Kompensasi Pengurangan Subsidi Bahan Bakar Minyak. Jakarta (ID): The Indonesian Institute. URL: https://www.neliti.com/publications/45113/evaluasi-rencana-kebijakan-programkompensasi-pengurangan-subsidi-bahan-bakar-mi\#cite (accessed: 09.10.2021).
} 
and before the program, respectively. Meanwhile, $Y^{c}{ }_{1}$ and $Y^{c}{ }_{0}$ respectively denotes the outcome for untreated individuals after and before the program. In a regression framework, the double-difference estimate can be calculated as follows:

$$
Y_{i t}=a+\beta T_{i 1} t+\rho T_{i 1}+\gamma t+\varepsilon_{i t} .
$$

In the equation, the coefficient $\beta$ shows the interaction between the post-program treatment variable $\left(\mathrm{T}_{i 1}\right)$ and time $(t=1 . . . T)$, giving the average DID effect of the program. Therefore, $\beta=D D$. While panel data is not necessary to implement the $D D$ approach, it is indeed necessary for BOS. There is no available counterfactual from other regions as the program is implemented in Indonesia as a whole. Considering this, the research uses the fixed effects model. This model controls for not only the unobserved time-invariant heterogeneity but also for heterogeneity in observed characteristics over a multiple-period setting:

$$
Y_{i t}=\varphi T_{i t}+\delta X_{i t}+\eta_{i}+\varepsilon_{i t}
$$

By differencing this equation, the source of endogeneity $\eta$ is dropped from the equation.

$$
\left(Y_{i t}-Y_{i t-1}\right)=\varphi\left(T_{i t}-T_{i t-1}\right)+\delta\left(X_{i t}-X_{i t-1}\right)+\left(\eta_{i}-\eta_{i}\right)+\left(\varepsilon_{i t}-\varepsilon_{i t-1}\right) .
$$

The result is the following equation:

$$
\Delta Y_{i t}=\varphi \Delta T_{i t}+\delta \Delta X_{i t}+\Delta \varepsilon_{i t}
$$

Ordinary least squares (OLS) can be used to estimate the $D D$ from the equation. In this equation, $\varphi$ is equal to the $D D$ estimate, controlling for the same covariates $X_{i t}$. In the case of impact evaluation for the BOS program, the model is as follows [Giles, Satriawan, 2015]:

Transition $_{i j t}=\beta_{0}+\beta_{1}$ BOSyr $_{i j}+\beta_{2} 2007$ dummy $_{t}+\beta_{3} B 0 S 07_{t}+\delta B O S_{i j} \times t+\beta_{34} X_{i j}+u_{i j t}$.

Where $T_{i j t}$ is the variable describing the transition to junior secondary school for individual $i$ in household $j$ in year $t$, where these individuals refer to youth who were in school before BOS was implemented. BOSyr is an interaction between BOS acceptance where "1" equals individual $i$ in household $j$ who received the BOS program in year $t$ and " 0 " equals individual $i$ in household $j$ who do not receive BOS in year $t$ and the dummy variable for year. The variable 2007 dummy is the year dummy, where " 1 " equals the year 2007. BOS07 is a dummy variable where " 1 " indicates the individual received BOS in 2007 . Other than that, $X_{i j}$ are household and individual characteristics variables, while $u_{i j t}$ is the error term for individual $i$ in household $j$ in year $t$. Equation (13) above, might cause bias if there are some characteristics of the household which is unobserved and it has a time-invariant that can affect the outcome. In addition, the bias can occur because of endogeneity problems that arise from household decisions to follow the program or not (self-selection bias). Thus, controlling program placement that is not random and unobserved characteristics of households and individuals within program participation is then anticipated by the fixed effects method at the household level so to overcome the bias problems. Thus, using the fixed effect method at the household level, equation (13) becomes as follows:

Transition $_{i j t}=\beta_{0}+\beta_{1}$ BOSyr $_{i j}+\beta_{2} 2007$ dummy $_{t}+\beta_{3}$ BOSO $_{t}+\delta B O S_{i j} \times t+\beta_{34} X_{i j}+\mu_{j}+v_{i j t}$. 


\section{Results and Discussion}

In this section, the author will discuss the distribution of the data and the proportions of school transition, School Operational Assistance Program (BOS) acceptance, household education, community, and individual characteristics. The data spans two years from the 2000 and 2007 rounds of the Indonesian Family Life Survey. The sample comprises 2,960 individuals. The dependent variable - school transition - includes only transition from primary school to junior secondary school. Instead of looking at each individual's transition, this data uses the transition rate in each community. In 2000 , the data comprised of 1,807 (61.05\%) female samples and 1,153 (38.95\%) male samples. BOS had not been implemented yet in 2000; hence, there is no BOS benefactor in the sample. On average, the transition rate from primary school to junior secondary school across 299 communities is 82.3 percent. BOS had been in effect in the 2007 rounds of the survey. From the sample, $1,808(61.08 \%)$ are female while $1,152(38.92 \%)$ are male. Of the 300 schools included in the study, $91.35 \%$ received the BOS program while the rest have not. On average, the transition rate in both education levels is lower than the previous year.

Table 1. Summary Statistics of Key Variables*

\begin{tabular}{|c|c|c|c|c|}
\hline \multirow{2}{*}{ VARIABLES } & \multicolumn{2}{|c|}{2000} & \multicolumn{2}{|c|}{2007} \\
\hline & Mean & SD & Mean & SD \\
\hline Transition rate from primary to junior secondary school & 0.8230 & 0.3220 & 0.6280 & 0.3340 \\
\hline Community has asphalt road (yes $=1$ ) & 0.7940 & 0.4050 & 0.8610 & 0.3450 \\
\hline Household has TV (yes $=1$ ) & 0.6110 & 0.4880 & 0.8020 & 0.3980 \\
\hline Household has its own toilet (yes $=1$ ) & 0.5880 & 0.4920 & 0.7260 & 0.44600 \\
\hline Household head is married (yes $=1$ ) & 0.9070 & 0.2900 & 0.8470 & 0.3600 \\
\hline Household head age & 44.4000 & 10.6000 & 49.4900 & 10.2600 \\
\hline Female household head (yes $=1$ ) & 0.1140 & 0.3170 & 0.1580 & 0.3650 \\
\hline Distance from nearest public telephone $(\mathrm{km})$ & 4.4130 & 11.3400 & 2.2200 & 6.3650 \\
\hline Distance from nearest market $(\mathrm{km})$ & 2.0780 & 2.9770 & 2.6330 & 4.5930 \\
\hline District capital center $(\mathrm{km})$ & 20.9000 & 27.9700 & 24.0800 & 58.4800 \\
\hline Number of Junior secondary schools in the community & 3.6170 & 1.6680 & 3.5160 & 1.8610 \\
\hline Number of high schools in the community & 3.3560 & 2.2890 & 3.1440 & 1.9920 \\
\hline Wealth Index & 3.1270 & 1.3690 & 3.2590 & 1.3740 \\
\hline Age of Child & 9.9690 & 2.2020 & 17.2600 & 2.1980 \\
\hline Gender of Child (girls $=1$ ) & 0.3890 & 0.4880 & 0.3890 & 0.4880 \\
\hline \multicolumn{5}{|l|}{ HH Head Education } \\
\hline No school & 0.1090 & 0.3110 & 0.0930 & 0.2910 \\
\hline Primary school & 0.5440 & 0.4980 & 0.5320 & 0.4990 \\
\hline Junior secondary school & 0.1270 & 0.3330 & 0.1200 & 0.3250 \\
\hline High school & 0.1360 & 0.3430 & 0.1450 & 0.3520 \\
\hline University & 0.0440 & 0.2060 & 0.0560 & 0.2310 \\
\hline HH head works (yes = 1) & 0.8990 & 0.3010 & 0.8020 & 0.3340 \\
\hline Farm business ownership & 0.3810 & 0.4860 & 0.3900 & 0.4880 \\
\hline Rural (yes $=1$ ) & 0.5700 & 0.4950 & 0.5300 & 0.4990 \\
\hline Household size & 5.6460 & 1.8740 & 5.1680 & 1.7940 \\
\hline Per capita expenditure (log) & 11.850 & 0.6650 & 12.810 & 0.6260 \\
\hline
\end{tabular}


In $2000,79.4 \%$ of the surveyed community had an asphalt road, and the number increased to $86.1 \%$ in 2007 . A household's distance to the nearest public telephone average at $4.4 \mathrm{~km}$ in 2000 and decreased to $2.2 \mathrm{~km}$ in 2007 . The average household distance from the nearest market increased from $2 \mathrm{~km}$ in 2000 to $2.6 \mathrm{~km}$ in 2007 . Other than community variables, household characteristics are also used. Dummy variables to indicate toilet and TV ownership, the household head's characteristics, the household's wealth index, per capita expenditure, household size, and household head's education. Only $61.1 \%$ of households owned a TV in 2000 compared to 2007 with $80.2 \%$ TV ownership. More households also owned a toilet in 2007 , with $58.8 \%$ in 2000 and $72.6 \%$ in 2007. On average, households' heads were older in 2007 (49 years old) compared to 2000 (44 years old). Around $90 \%$ of household heads were married in 2000 compared to $84.7 \%$ in 2007 . There are more households with female heads in 2007 with $15.8 \%$ compared to $11.4 \%$ in 2000 . By wealth index, the data are about equally divided into five different quintiles. On average, households are smaller in 2007 than in 2000. In 2000, the average household consisted of 5.6 individuals, while in 2007, it consisted of 5.2 individuals.

Table 2 shows the results of Ordinary Least Square (OLS) and Fixed Effects (FE) to analyze the impact of the School Operational Assistance program (BOS) on the quality of education in Indonesia, particularly in the transition rate. Since its implementation, the program has constantly been improved and channeled more funding to primary and junior secondary schools in Indonesia. While the program has been in effect for fifteen years, this study evaluated the program only from its implementation in 2005 to 2007 . The result showed that the BOS program increases the transition rate by 7.63 percentage points, significant at a $99 \%$ confidence level, assuming ceteris paribus. The regression results show that the BOS program has a positive impact on the quality of education in Indonesia. This is in line with a study on similar programs in other countries such as PROGRESA in Mexico [Attanasio, Meghir, Santiago, 2001; Schultz, 2004; Skoufias, McClafferty, 2001] that found the program successfully increased the enrollment rate for areas affected. The results are also similar to Behrman et al. [2005], who found not only the program's effect on drop-out rate and enrollment but also the transition from primary to junior secondary school. Other studies with similar results are Galiani and McEwan [2013) and Cardoso and Souza [2004].

To discuss how BOS may impact education quality, it is essential to note that BOS is only part of a government mandate to allocate at least $20 \%$ of the government budget to the education sector. Between 2005 and 2009, Indonesia's education budget has increased by $60 \%{ }^{7}$. Of the new budget, most of it is allocated to double teacher salaries following the Teacher Law of 2005. The teacher reform was to increase the quality of education by incentivizing existing teachers to improve their competence, while BOS aims to increase access for low-income students. While the thesis only conducted an impact evaluation from 2005-2007, it is notable that BOS was updated in 2009 to improve the quality of education. This includes the provision of teaching aids, teaching materials, supporting teachers' training, and recruitment of specialized teachers.

\footnotetext{
7 World Bank. (2013) Indonesia - Spending More or Spending Better: Improving Education Financing in Indonesia. The World Bank Report. No. 73050. Jakarta (ID): World Bank. URL: https://openknowledge.worldbank.org/handle/10986/13210 (accessed: 09.10.2021).
} 
Hopefully, this improvement will increase the quality of schools in Indonesia, hand in hand with the teacher reform.

Many of the problems with BOS lies in its management. The grant is disbursed once every three months and depends on the number of students in each school. However, OECD reported that the funds often arrive late or did not arrive at all [Parker, Prabawa-Sear, 2019]. The formula also does not account for the difference in operating costs between different schools. Fixed costs, such as having an electrical supply or a library, are roughly the same for schools regardless of size. This puts smaller schools at a disadvantage, with half of the primary schools in Indonesia having less than 150 students. Furthermore, a challenge with both BOS allocations is that using a per-student formula does not consider the differences in operating costs schools face due to the particular populations they serve and their locations. Schools in remote areas serving low-income households are likely to require more resources to provide a level of education, similar to a school in a higher-income area. The cost of school supplies can also vary significantly between accessible and more remote areas because of the associated transportation costs. Then there are also fixed costs, such as having an electrical supply, a water point, having an administration office, a library, etc., which are roughly the same for schools no matter what the size [ibidem].

While heavily regulated in its use of funds, the BOS program has little to no quality control. The program requires every school to have its team manage the BOS funds and write reports detailing the fund's usage to ensure the money is not used for other purposes. However, there is no required outcome in terms of quality. The control ends at what the funds are used for, not whether it improves learning for the students. Consequently, the school has little to no incentive to use the funds efficiently to enhance the learning outcome. A quality control mechanism linked to BOS funds could improve the overall quality of education. There is a disparity between school accreditation provided by National Accreditation Agency (BAN) and the minimum service standards in Indonesia. In 2013, around $98 \%$ of schools passed accreditation, with $83 \%$ graded $A / B$ (with $A$ as the highest accreditation and $D$ for non-accredited schools). However, there are very few schools that meet the minimum service standards [ibidem]. Strengthening the accreditation system and linking it with BOS distribution could serve as a quality control mechanism.

Table 2. Impact Estimation of BOS to Transition Rate from Primary to Junior secondary school*

\begin{tabular}{lcccc}
\multirow{2}{*}{ Variables } & OLS & Fixed Effect & OLS & Fixed Effect \\
\cline { 2 - 5 } & $(1)$ & $(2)$ & $(3)$ & $(4)$ \\
\hline \multirow{2}{*}{ Year dummy } & $-0.2312^{* * *}$ & $-0.2026^{* * *}$ & $-0.2232^{* * *}$ & $-0.2091^{* * *}$ \\
Difference-in-differences & {$[0.0182]$} & {$[0.0193]$} & {$[0.0192]$} & {$[0.0246]$} \\
& $0.1274^{* * *}$ & $0.0877^{* * *}$ & $0.1157^{* * *}$ & $0.0763^{* * *}$ \\
Primary school & {$[0.0194]$} & {$[0.0208]$} & {$[0.0196]$} & {$[0.0219]$} \\
& & & $0.0730^{* * *}$ & 0.0085 \\
Junior secondary school & & & {$[0.0133]$} & {$[0.0282]$} \\
& & & $0.0800^{* * *}$ & 0.0136 \\
& & & {$[0.0154]$} & {$[0.0352]$}
\end{tabular}




\begin{tabular}{|c|c|c|c|c|}
\hline \multirow{2}{*}{ Variables } & OLS & Fixed Effect & OLS & Fixed Effect \\
\hline & $(1)$ & $(2)$ & (3) & (4) \\
\hline \multirow{2}{*}{ Senior secondary school } & & & $0.0989^{* * *}$ & 0.0263 \\
\hline & & & {$[0.0154]$} & {$[0.0388]$} \\
\hline \multirow{2}{*}{ University } & & & $0.1185^{* * *}$ & 0.0430 \\
\hline & & & {$[0.0186]$} & [0.0505] \\
\hline \multirow{2}{*}{ Wealth index } & & & $0.0114^{* * *}$ & $0.0145^{* *}$ \\
\hline & & & {$[0.0034]$} & [0.0063] \\
\hline \multirow{2}{*}{ Sex of Household Head } & & & 0.0016 & -0.0076 \\
\hline & & & {$[0.0140]$} & [0.0311] \\
\hline \multirow{2}{*}{ Household Head marital status } & & & -0.0126 & 0.0135 \\
\hline & & & [0.0143] & [0.0289] \\
\hline \multirow{2}{*}{ Household Head Age } & & & 0.0001 & 0.0006 \\
\hline & & & {$[0.0003]$} & {$[0.0008]$} \\
\hline \multirow{2}{*}{ Household head works } & & & 0.0051 & 0.0008 \\
\hline & & & [0.0104] & [0.0199] \\
\hline \multirow{2}{*}{ TV ownership } & & & -0.0046 & -0.0119 \\
\hline & & & {$[0.0080]$} & {$[0.0155]$} \\
\hline \multirow{2}{*}{ Household size } & & & $-0.0035^{*}$ & 0.0007 \\
\hline & & & {$[0.0019]$} & [0.0052] \\
\hline \multirow{2}{*}{ Per capita expenditure (log) } & & & -0.0095 & 0.0066 \\
\hline & & & {$[0.0061]$} & [0.0123] \\
\hline \multirow{2}{*}{ Household has its own toilet } & & & $0.0420^{* * *}$ & $0.0253^{*}$ \\
\hline & & & {$[0.0072]$} & {$[0.0147]$} \\
\hline \multicolumn{5}{|l|}{ Community characteristics } \\
\hline \multirow{2}{*}{ Farm business ownership } & & & 0.0069 & $0.0286^{* *}$ \\
\hline & & & {$[0.0068]$} & {$[0.0126]$} \\
\hline \multirow{2}{*}{ District capital center } & & & $0.0003^{* * *}$ & $0.0001^{* *}$ \\
\hline & & & {$[0.0000]$} & {$[0.0000]$} \\
\hline \multirow{2}{*}{ Community has asphalt road } & & & 0.0124 & 0.0008 \\
\hline & & & {$[0.0082]$} & {$[0.0176]$} \\
\hline \multirow{2}{*}{ Distance from the public telephone } & & & $0.0007^{* *}$ & $-0.0017^{*}$ \\
\hline & & & {$[0.0003]$} & [0.0009] \\
\hline \multirow{2}{*}{ Distance from the nearest market } & & & 0.0011 & $0.0047^{* * *}$ \\
\hline & & & {$[0.0008]$} & [0.0012] \\
\hline \multirow{2}{*}{ Number of schools in the community } & & & $0.0110^{* * *}$ & $0.0081^{* * *}$ \\
\hline & & & {$[0.0017]$} & {$[0.0026]$} \\
\hline \multirow[b]{2}{*}{ Constant } & $0.6633^{* * *}$ & $0.5840^{* * *}$ & $0.6438^{* * *}$ & $0.3976^{* *}$ \\
\hline & {$[0.0093]$} & [0.0035] & {$[0.0785]$} & {$[0.1694]$} \\
\hline $\mathrm{R}^{2}$ & 0.0731 & 0.1938 & 0.1135 & 0.2140 \\
\hline
\end{tabular}

*Note: Robust standard errors in brackets; ${ }^{*} p<0.1,{ }^{* *} p<0.05,{ }^{* * *} p<0.01$. 
The regression results show that a higher wealth index would increase the transition rate by 1.45 percentage points, significant at $5 \%$, assuming ceteris paribus. This is in line with the model made by Colclough, Rose, and Tembon [2000], which described how children from low-income households are less likely to continue schooling due to high direct costs for education. This persists even when the families are not charged with school fees because they would still incur various expenditures such as uniforms or textbooks.

Other variables related to the household head are also insignificant, such as sex, marital status, age, and employment. Household characteristics such as TV ownership, household size, and per capita expenditure are also insignificant. Holding everything else equal, toilet ownership in every household increase transition rate by 2.53 percentage point, significant at $10 \%$. Toilet ownership is highly related to sanitation, with evidence pointing that better access to water and sanitation in a household would improve the child's educational attainment as it improves their overall health [Santiago Ortiz-Correa, Resende Filho, Dinar, 2016].

When there are two similar households, and one owns a farming business, the farm business owner has a 2.86 percentage point higher transition rate significant at $5 \%$. Children who came from families that own farm businesses, often dubbed a farm family, have an inversely proportional school enrolment to the size of their farmland [Rosenzweig, 1977]. With more than half the farms in Indonesia being small (less than 0.5 hectares in size), these farm-families need to diversify their income to meet their family needs and equip their children with schooling to find income from non-farm employment [Sudaryanto, Susilowati, Sumaryanto, 2009].

The community variables, distance from the district office, distance from the nearest public telephone, and distance from the nearest market represent how far the household lives from the city center and how easy it is to fulfill their needs. The model shows that one additional kilometer from the district office increases the transition rate by 0.01 percentage point, significant at $5 \%$, ceteris paribus. With each kilometer farther the household is from the nearest public telephone, the transition rate decreases by 0.17 percentage point ceteris paribus, significant at $10 \%$. The further a household is to the nearest market; each kilometer increases the transition rate by 0.47 percentage points, significant at $1 \%$. Each additional junior secondary school in a community would increase the transition rate by 0.81 percentage point significant at $1 \%$, ceteris paribus. In addition to the previously mentioned SD Inpres program, which showed an investment in infrastructure improves school enrollment [Duflo, 2001], similar results are found by Handa [2002]. Building more schools is a more effective intervention than raising household income on school enrolment rates.

The research also used difference-in-differences regression to evaluate the effect of BOS on boys and girls. From the difference-in-difference estimation, BOS is estimated to increase the transition rate for girls by 9.02 percentage points, significant at $1 \%$. In comparison, the program increases the transition rate for boys by 5.33 percentage points, significant at $10 \%$ (see table 3 ). The results show that there is a difference in how the program impact student of different genders. The model shows that boys are less impacted by the School Operational Assistance Program (BOS). This finding is in line with research suggesting the emergence of a schooling advantage for girls in 
areas that favored boys. Schuler [2007] found that in Bangladesh in 2004, girls had higher school participation compared to boys for students younger than fifteen. In the 15-19-year-old age range, girls still had obtained better grades. An advantage for girls has also been found in Nigeria, Egypt, and Thailand (Smith, 2001; Tfaily, 2016; Knodel, Chayovan, Graiurapong, Suraratdecha, 2000).

Meanwhile, results from a study comparing gender gaps in education in 38 developing countries show that boys are more likely to be enrolled in school; however, girls in schools have better grades and continue to be in school higher than boys [Grant, Behrman, 2010]. One reason is that countries with similar programs like BOS, such as Mexico, provide higher incentives for girls rather than boys. The study included data from the Philippines, Vietnam, and Indonesia for the Southeast Asia region. In all age groups included, the study suggests that girls in school have equal, if not better, school grades and progress than boys. This result stays true for most areas in the study, including the Southeast Asia region. The percentage of female students attending junior secondary school is also higher when compared to boys.

Table 3. Impact Estimation of BOS to Transition Rate from Primary to Junior Secondary School by Gender*

\begin{tabular}{|c|c|c|c|c|}
\hline \multirow{3}{*}{ Variables } & \multicolumn{2}{|c|}{ Girls } & \multicolumn{2}{|c|}{ Boys } \\
\hline & OLS & Fixed Effects & OLS & Fixed Effects \\
\hline & (1) & (2) & (3) & (4) \\
\hline \multirow[t]{2}{*}{ Year dummy } & $-0.2337^{* * *}$ & $-0.2123^{* * *}$ & $-0.2051^{* * *}$ & $-0.1685^{* * *}$ \\
\hline & {$[.0256]$} & [0.0314] & [0.0285] & [0.0404] \\
\hline \multirow[t]{2}{*}{ Difference-in-differences } & $0.1313^{* * *}$ & $0.0902^{* * *}$ & $0.0940^{* * *}$ & $0.0533^{*}$ \\
\hline & {$[.0262]$} & {$[0.0284]$} & {$[0.0289]$} & [0.0304] \\
\hline \multirow[t]{2}{*}{ Constant } & $0.5744^{* * *}$ & $0.4799^{* *}$ & $0.7762^{* * *}$ & $0.4550^{*}$ \\
\hline & [0.1022] & [0.1962] & [0.1233] & [0.2688] \\
\hline $\mathrm{R}^{2}$ & 0.1047 & 0.2080 & 0.1376 & 0.2326 \\
\hline$N$ & 2894 & 2894 & 1859 & 1859 \\
\hline
\end{tabular}

*Note: Robust standard errors in brackets; ${ }^{*} p<0.1,{ }^{* *} p<0.05,{ }^{* * *} p<0.01$. Additional controls: household head education, wealth index, sex of household head, household head marital status, household head age, household head works, tv ownership, household size, per capita expenditure (log), household has its own toilet, farm business ownership, district capital center, community has asphalt road, distance from the public telephone, distance from the nearest market, number of schools in the community are included but not reported.

Table 4 displays the final calculations of the estimation by OLS and fixed effects by regions. Aside from gender, the study also compared the impact of BOS on rural and urban children. The model estimated that the school operational assistance program increased the transition rate in rural areas by 16.09 percentage points, significant at $1 \%$, assuming ceteris paribus.

When comparing the program's impact in rural and urban areas, the regression found that the program did not significantly impact students in urban areas. A meta-analysis of conditional cash transfer (CCT) programs on educational outcomes in developing countries by Saavedra and Garcia [2012] conclude that CCT programs 
are more effective when initial enrollment and attendance conditions are relatively low-income. Considering the difference in initial enrollment between rural and urban areas in Indonesia, it is possible that this condition also applies. A review by OECD ${ }^{8}$ also mentioned that while the BOS program helped all schools, it particularly helped those who live in low-income and remote areas and who lacked an education budget in the first place.

Table 4. Impact Estimation of BOS to Transition Rate from Primary to Junior Secondary School by Area*

\begin{tabular}{lcccc}
\multirow{2}{*}{ Variables } & \multicolumn{2}{c}{ Rural } & \multicolumn{3}{c}{ Urban } \\
\cline { 2 - 5 } & OLS & Fixed Effect & OLS & Fixed Effect \\
\cline { 2 - 5 } Year dummy & $(1)$ & $(2)$ & $(3)$ & $(4)$ \\
\hline \multirow{2}{*}{ Difference-in-differences } & $-0.2733^{* * *}$ & $-0.2453^{* * *}$ & $-0.2020^{* * *}$ & $-0.2462^{* * *}$ \\
& {$[0.0315]$} & {$[0.0355]$} & {$[0.0223]$} & {$[0.0415]$} \\
Constant & $0.2160^{* * *}$ & $0.1609^{* * *}$ & 0.0288 & 0.0293 \\
& {$[0.0323]$} & {$[0.0347]$} & {$[0.0223]$} & {$[0.0321]$} \\
$\mathrm{R}^{2}$ & $0.5450^{* * *}$ & $0.6084^{* * *}$ & $0.7900^{* * *}$ & 0.1418 \\
$N$ & {$[0.1044]$} & {$[0.2128]$} & {$[0.1199]$} & {$[0.2783]$} \\
\hline
\end{tabular}

* Note: Robust standard errors in brackets; ${ }^{*} p<0.1,{ }^{* *} p<0.05,{ }^{* * *} p<0.01$. Additional controls: household head education, wealth index, sex of household head, household head marital status, household head age, household head works, tv ownership, household size, per capita expenditure (log), household has its own toilet, farm business ownership, district capital center, community has asphalt road, distance from the public telephone, distance from the nearest market, number of schools in the community are included but not reported.

\section{Conclusion}

Several findings can be concluded in this study. Firstly, the results of this study show that BOS has proven effective as a policy instrument to increase the opportunity for all children to complete the basic nine-year study program, prevent drop-out rates and equalize access to education with rising transition rates primary and junior secondary education.

Secondly, the BOS program significantly increases the level of school transition, especially for girls versus boys. This shows that BOS can reduce gender disparity in education and help more children, especially girls, get a longer and better education or participation so that they have the skills to build the future and ultimately escape poverty.

Thirdly, the existence of BOS can increase the level of school transition from primary to junior secondary education, especially in rural areas. This shows BOS can provide significant funding to address accessibility, equality in participation, break-up, and school transition, and those located in rural and remote areas. BOS has been shown to help all schools, particularly low-income and more remote areas, many of which previously lacked an education budget. "One Roof" primary and junior secondary schools, which share a building, have also been influential in increasing equitable access to

8 OECD 2015. URL: https://www.oecd.org/indonesia/education-in-indonesia-9789264230750-en.htm (accessed: 09.10.2021). 
basic education, particularly in remote areas. A school rehabilitation program has helped improve learning environments and strengthen school-based decision-making.

This study's limitation is data usage from the 2000 and 2007 survey rounds of the Indonesian Family Life Survey. The School Operational Assistance Program was changed in 2009, and the results of this paper may not be representative of the impact of the BOS program after the change in 2009. Further research recommends including the 2014 round of the Indonesian Family Life Survey with different methods.

\section{Policy Implications}

In contrast to the success of BOS in accelerating the completion of the basic education, increasing the transition rate, reducing drop-outs, and equal distribution of access to education. However, in implementing BOS funds, it still faces obstacles in the planning and evaluation processes and reporting on the management of BOS funds. Therefore, it is necessary to have the participation of all parties to control the BOS implementation, from the socialization to the level of supervision to improve Indonesia's overall quality of education.

\section{References}

Attanasio O.P., Meghir C., Santiago A. (2011) Education Choices in Mexico: Using a Structural Model and a Randomized Experiment to Evaluate PROGRESA. Review of Economic Studies. Vol. 79. No. 1. P. 37-66. https://doi.org/10.1093/restud/rdr015.

Barro R. (1991) Economic Growth in a Cross Section of Countries. The Quartely Journal of Economics. Vol. 106. No. 2. P. 407-443. https://doi.org/10.2307/2937943.

Becker G. S. (1964) Human Capital: A Theoretical and Empirical Analysis, with Special Reference to Education. Cambridge, MA: NBER. URL: https://www.nber.org/booksand-chapters/human-capital-theoretical-and-empirical-analysis-special-referenceeducation-first-edition (accessed: 07.10.2021).

Behrman J., Sengupta P., Todd P. (2005) Progressing through PROGRESA: An Impact Assessment of a School Subsidy Experiment in Rural Mexico. Economic Development and Cultural Change. Vol. 54. No. 1. P. 237-275. https://doi.org/10.1086/431263.

Cardoso E., Souza A. (2004) The Impact of Cash Transfers on Child Labor and School Attendance in Brazil. Vanderbilt University Department of Economics Working Papers. No. 0407. URL: http://hdl.handle.net/1803/20 (accessed: 07.10.2021).

Colclough C., Rose, P., Tembon M. (2000) Gender Inequalities in Primary Schooling: The Roles of Poverty and Adverse Cultural Practice. International Journal of Educational. Vol. 20. P. 5-27.

De Janvry A., Sadoulet E. (2006) Making Conditional Cash Transfer Programs More Efficient: Designing for Maximum Effect of the Conditionality. World Bank Economic Review. Vol. 20. No. 1. P. 1-29. https://doi.org/10.1093/wber/lhj002.

Di Gropello E. (2003) Monitoring Educational Performance in the Caribbean. World Bank Working Papers. Vol. 6. No. 6. https://doi.org/10.1596/0-8213-5516-3. 
Duflo E. (2001) Schooling and Labor Market Consequences of School Construction in Indonesia: Evidence from an Unusual Policy Experiment. American Economic Review. Vol. 91. No. 4. P. 795-813. https://doi.org/10.1257/aer.91.4.795.

Filmer D., Schady N. (2006) Getting Girls into School: Evidence from a Scholarship Program in Cambodia. Policy Research Working Paper. No. 3910-IE. Washington, DC: World Bank. URL: https://openknowledge.worldbank.org/handle/10986/8962 (accessed: 08.10.2021).

Galiani S., McEwan P. J. (2013) The Heterogeneous Impact of Conditional Cash Transfer. Journal of Public Economics. Vol. 103. P. 85-96. https://doi.org/10.1016/ j.jpubeco.2013.04.004.

Giles J., Satriawan E. (2015) Protecting Child Nutritional Status in the Aftermath of a Financial Crisis: Evidence from Indonesia. Journal of Development Economics. Vol. 114. P. 97-106. https://doi.org/10.1016/j.jdeveco.2014.12.001.

Grant M. J., Behrman J.R. (2010) Gender Gaps in Educational Attainment in Less Developed Countries. Population and Development Review. Vol. 36. No. 1. P. 71-89. https://doi.org/10.1111/j.1728-4457.2010.00318.x.

Handa S. (2002) Raising Primary School Enrolment in Developing Countries. The Relative Importance of Supply and Demand. Journal of Development Economics. Vol. 69. No. 1. P. 103-128. https://doi.org/10.1016/S0304-3878(02)00055-X.

Khandker S. R., Koolwal G. B., Samad H. A. (2009) Handbook on Impact Evaluation: Quantitative Methods and Practices. Washington, DC: World Bank Publications. https://doi.org/10.1596/978-0-8213-8028-4.

Kharisma B., Satriawan E., Arsyad L. (2017) The Impact of Social Safety Net Scholarships Program to School Dropout Rates in Indonesia: The Intention-to-Treat Analysis. The Journal of Developing Areas. Vol. 51. No. 4. P. 303-316. https://doi.org/10.1353/jda.2017.0103.

Knodel J., Chayovan N., Graiurapong S., Suraratdecha C. (2000) Ageing in Thailand: An Overview of Formal and Informal Support. Ageing in the Asia-Pacific Regions: Issues and Policies. No. 99. P. 243-266. https://doi.org/10.4324/9780203463086-17.

Mankiw N. G., Romer D., Weil D. N. (1992) A Contribution to the Empirics of Economic Growth. The Quarterly Journal of Economics. Vol. 107. No. 2. P. 407-437. https://doi.org/ 10.2307/2118477.

Parker L., Prabawa-Sear K. (2019) Education in Indonesia. In: L. Parker, K. PrabawaSear (eds.) Environmental Education in Indonesia. London: Routledge. P. 79-94.

Riccio J., Decgayssay N., Greenberg D., Miller C., Rucks Z., Verma N. (2010) Toward Reducing Poverty Across Generations: Early Findings from New York City's Conditional Cash Transfer Program. New York, NY: MDRC.

Rosenzweig M. (1977) Farm-Family Schooling Decisions: Determinants of the Quantity and Quality of Education in Agricultural Populations. The Journal of Human Resources. Vol. 12. No. 1. P. 71-91. https://doi.org/10.2307/145599. 
Saavedra J. E., Garcia S. (2012) Impacts of Conditional Cash Transfer Programs on Educational Outcomes in Developing Countries. RAND Working Paper. No. WR-921-1. Santa Monica, CA: RAND Corporation. https://doi.org/10.7249/WR921-1.

Santiago Ortiz-Correa J., Resende Filho M., Dinar A. (2016) Impact of Access to Water and Sanitation Services on Educational Attainment. Water Resources and Economics. Vol. 14. P. 31-43. https://doi.org/10.1016/j.wre.2015.11.002.

Schuler S. R. (2007) Rural Bangladesh: Sound Policies, Evolving Gender Norms, and Family Strategies. In: M. A. Lewis, M. E. Lockheed (eds.) Exclusion, Gender and Education: Case Studies from the Developing World. Washington, DC: Center for Global Development. P. 179-201.

Schultz T. P. (2004) School Subsidies for the Poor: Evaluating the Mexican Progresa Poverty Program. Journal of Development Economics. Vol. 74. No. 1. P. 199-250. https://doi.org/10.1016/j.jdeveco.2003.12.009.

Skoufias E., McClafferty B. (2001) Is PROGRESA working? Summary of the Results of an Evaluation by IFPRI. FCND Discussion Paper. No. 118. Washington, DC: International Food Policy Research Institute. URL: https://core.ac.uk/download/pdf/6289438.pdf (accessed: 09.10.2021).

Smith D. J. (2001) "These Girls Today Na War-0": Premarital Sexuality and Modern Identity in Southeastern Nigeria. Africa Today. Vol. 47. No. 3/4. P. 99-120. https:// doi.org/10.2979/AFT.2000.47.3-4.98.

Sudaryanto T., Susilowati S. H., Sumaryanto S. (2009) Increasing Number of Small Farms in Indonesia: Causes and Consequences. Conference Paper: 111 EAAE-IAAE Seminar "Small Farms: Decline or Persistence". 26-27 June. Canterbury: University of Kent. https://doi.org/10.22004/ag.econ.52808.

Sulistyaningrum E. (2016) Impact Evaluation of the School Operational Assistance Program (Bos) Using the Matching Method. Journal of Indonesian Economy and Business. Vol. 31. No. 1. P. 33-62. https://doi.org/10.22146/jieb.10319.

Suryadarma D., Suryahadi A., Sumarto S. (2006) Causes of Low Secondary School Enrollment. Working Paper. August. Jakarta: The SMERU Research Institute. URL: https://smeru.or.id/sites/default/files/publication/enrollmenteng06.pdf (accessed: 09.10.2021).

Tfaily R. (2016) Sexospécificité, Composition de la Aratrie et Education en Egypte. Comparative Education Review. Vol. 60. No. 3. P. 480-500. https://doi.org/10.1086/ 687204. 